\title{
Role of splenic stroma in the action of bacterial lipopolysaccharides on radiation mortality: a study in mice carrying the $\mathrm{Sl}^{\mathrm{j}}$ allele
}

\author{
R. E. Ploemacher and N. H. C. Brons \\ Department of Cell Biology and Genetics, Erasmus University, Rotterdam. The Netherlands
}

(Received 10 June 1985; revision accepted 9 October 1986)

\begin{abstract}
Sj} /+$ mice display a slight macrocytic anaemia due to a defect in their haemopoietic organ stroma. They have a deficient endogenous spleen colony (CFUend) formation following sublethal doses of gamma-radiation compared with their normal $+/+$ littermates, which is likely to be due to the low pre-irradiation CFU-S content of the Sij/+ spleen. CFU-S in these congenic mice do not differ in their sensitivity to gamma-irradiation or stem cell-activating factor.

While injection of $+/+$ mice with $10 \mu \mathrm{g}$ of lipopolysaccharide-W (LPS) one day prior to irradiation led to a substantial increase in their survival, the survival of $\mathrm{Sl} /+$ mice was only slightly increased. Irradiation induced a similar dose-related reduction in the numbers of CFU-S in the spleen and femora of LPS-injected Sij/ mice compared to similarly treated $+/+$ mice when measured directly after irradiation. At Day 9 after irradiation, injection of LPS led to a significantly higher CFU-end formation and higher numbers of CFU-S and nucleated cells in the Sli/+ spleens compared to LPS-injected $+1+$ mice. No such differences in the radioprotective effect of LPS were observed in the $+/+$ and $\mathrm{Si} /+$ mice with respect to the splenic and femoral ${ }^{59} \mathrm{Fe}$-incorporation and the femoral CFU-S numbers at Day 9.

These data strongly suggest a contribution by immigrating CFU-S to the CFU-S numbers and endogenous colony formation in at least the $\mathrm{Sl} /+$ spleen after LPS injection and subsequent sublethal irradiation. The observations also imply that the splenic organ stroma may play a mediatory role in the radioprotective action of LPS. In addition, the data represent an extreme example of a lack of correlation between animal survival and haemopoietic parameters. Caution should be taken when applying endogenous colony counts as a means of screening potential anti-radiation drugs.
\end{abstract}

One of the intriguing biological properties of lipopolysaccharide (LPS) preparations from cell walls of Gram-negative bacteria is their ability to protect mice against lethal gamma-irradiation (Mefferd et al., 1953; Mori et al., 1978), and to induce a marked increase in the number of haemopoietic stem cells (CFU-S) surviving in the spleen of sublethally irradiated mice (Smith

Correspondence : R. E. Ploemacher, Department of Cell Biology and Genetics, Erasmus University, P.O. Box 1738, 3000 DR Rotterdam, The Netherlands. 
et al., 1966b; Hanks \& Ainsworth, 1967). The largest increase in CFU-S number is seen in circumstances which lead to the greatest survival rate of the animals. On the other hand, LPS and other radioprotective agents have been observed to increase the number of endogenous spleen colonies (CFU-end) when animal survival and marrow recovery were not increased (Brecher \& Smith, 1965; Smith et al., 1966a; Hanks \& Ainsworth, 1967; Mori \& Kitamura, 1976; Fujita et al., 1983). Although the effect of LPS is considered to be primarily due to an earlier onset of CFU-S regeneration and not to an increase in population size of splenic CFU-S following LPS injection, and preceding the irradiation (Smith et al., 1963, 1966a,b; Brecher et al., 1967), it has been suggested that enhanced migration of CFU-S from bone marrow to spleen may lead to an overestimation of the splenic CFU-S survival following irradiation (Smith et al., $1966 \mathrm{a}, \mathrm{b})$. We have compared animal survival with various haemopoietic parameters following irradiation with special reference to the protective effects of LPS. With this in mind we studied congenic mice of the 129 strain, which differ in their respective splenic and femoral contents of CFU-S (Ploemacher \& Brons, 1984). Although the femoral CFU-S population size in Si/ + mice is subnormal ( $82 \%$ in their normal $+/+$ littermates), the splenic CFU-S numbers amount to $36 \%$ only, due mainly to a defect in the splenic stroma (Ploemacher \& Brons, 1984; Ploemacher et al., 1984a,b). We expected that any LPS-induced migration of CFU-S from the bone marrow to the spleen would give rise to a relatively greater enhancement of splenic CFU- end-numbers in irradiated $\mathrm{Sl}^{\mathrm{j}} /+$ mice than in similarly treated $+/+$ mice. Moreover, these congenic mice offered a valuable tool to study the role of the spleen in the reduction of post-irradiation mortality by LPS, and the mechanism by which its radioprotection might act.

\section{MATERIALS AND METHODS}

Female 129/SvSjiCP mice were derived from animals originally obtained from the Jackson Laboratory, Bar Harbor, U.S.A. Si $/+$ and $+1+$ mice were bred at the Laboratory Animal Center of the Erasmus University by natural matings between male $\mathrm{Si} /+$ and female $+1+$ mice, to yield an equal number of $+1+$ and $\mathrm{Si} /+$ segregants. Animals were maintained under constant light. Food pellets and acidified ( $\mathrm{pH} 2.8$ ) water were available ad libitum.

Mice were injected intravenously (i.v.) with $10 \mu \mathrm{g}$ Salmonella typhosa lipopolysaccharide prepared according to Westphal (Sigma, St Louis), or balanced salt solution (BSS).

CFU-S numbers were determined as described by Till \& McCulloch (1961). Mice were irradiated with a 137Cs gamma source (Gammacell 40, Atomic Energy of Canada, Ltd, Ottawa, Canada; dose rate $1.28 \mathrm{~Gy} / \mathrm{min}$ ). Recipient mice in the exogenous colony assay received a lethal dose of total body irradiation $(9.0 \mathrm{~Gy})$. Three hours following irradiation they were injected with varying numbers of bone marrow or spleen cells. Colonies in at least ten spleens were counted on Day 8. Endogenous spleen colonies (Till \& McCulloch, 1963) were counted on Day 9. A modified logarithmic transformation was used to correct for their skewed distribution and the existence of zero counts (Smith et al., 1966a). Briefly, 1 was added to the colony count per spleen, the logarithm was taken and used as an estimate of the median. This data reduction yielded median values which regressed linearly with dose. The reciprocal transformation of the log median gave the data presented here. The radiation dose that reduces the endogenous spleen colony numbers down to $37 \%$ (D37) was calculated with the help of the fitted lines in Fig. 1. Erythropoietic activity in the spleen and femoral bone marrow was measured at two and nine days following irradiation by injecting $1 \mu \mathrm{Ci}$ of ${ }^{59} \mathrm{Fe}$-citrate per mouse i.v. $6 \mathrm{hr}$ before the mice were killed. Radioactivity was quantified using a Packard Auto Gamma Scintillation Spectrometer. 


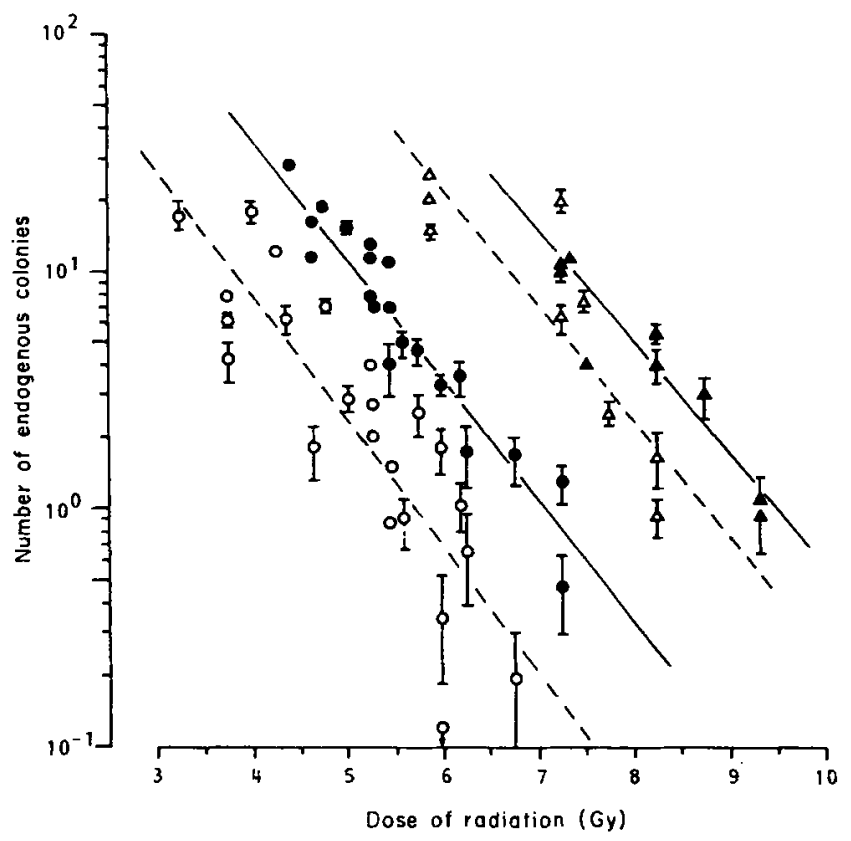

Fig. 1. Effect of LPS on the endogenous spleen colony formation in congenic mice of the 129 strain. $(O, \triangle)$ The mutant $\mathrm{S} H /+$ mice; $(\boldsymbol{O}, \boldsymbol{\Delta})$, normal $+1+$ littermates. Triangular symbols denote mice that were pretreated with $10 \mu \mathrm{g}$ of LPS $24 \mathrm{hr}$ before irradiation, whereas circular symbols represent mice that did not receive LPS (B58).

\section{RESULTS}

\section{Endogenous colony formation}

Endogenous colony formation in $\mathrm{Sl}^{\mathrm{j}} /+$ mice was deficient in comparison with normal $+1+$ mice (Fig. 1). The spleens of normal mice contained five times as many colonies as $\mathrm{Sl} /+$ spleens at nine days after sublethal irradiation with the same doses (D37 for $+1+$ mice, 85.2 cGy; D37 for $\mathrm{Si} /+$ mice, $81 \cdot 0 \mathrm{cGy}$ ).

Following an i.v. injection of $10 \mu \mathrm{g}$ of LPS one day before irradiation, the same number of CFU-end as without LPS pretreatment was obtained in $+1+$ mice with a radiation dose increased by $2.3 \mathrm{~Gy}$ (D37, $91.4 \mathrm{cGy}$ ). LPS-treated $\mathrm{Si} /+$ mice needed an extra $2.9 \mathrm{~Gy}$ to produce the same CFU-end number as their respective controls (D37, 87.9 cGy), this suggests a larger protective effect of LPS on the haemopoietic activity in these mice. The dose modification factors (DMF) for CFU-end in LPS-injected mice are given in the upper line of Table 1.

\footnotetext{
Animal survival

Pretreatment of $+/+$ mice with $10 \mu \mathrm{g}$ of LPS (Fig. 2) increased their LD 50/30 for gammairradiation from 7.53 to $8.80 \mathrm{~Gy}$, which represents a dose modification factor (DMF) of 1.16. In $\mathrm{Si} /+$ mice, however, LPS had a negligible radioprotective effect as shown by an increase in the LD 50/30 from 7.75 to 7.93 Gy (DMF, 1.02). The DMF for survival of $+1+$ mice was significantly lower than the DMF calculated for endogenous spleen colony formation (Table 1). The difference in DMF calculated on the basis of endogenous spleen colony formation and animal survival was much larger in $\mathrm{Sj} /+$ mice than in $+/+$ mice.
} 


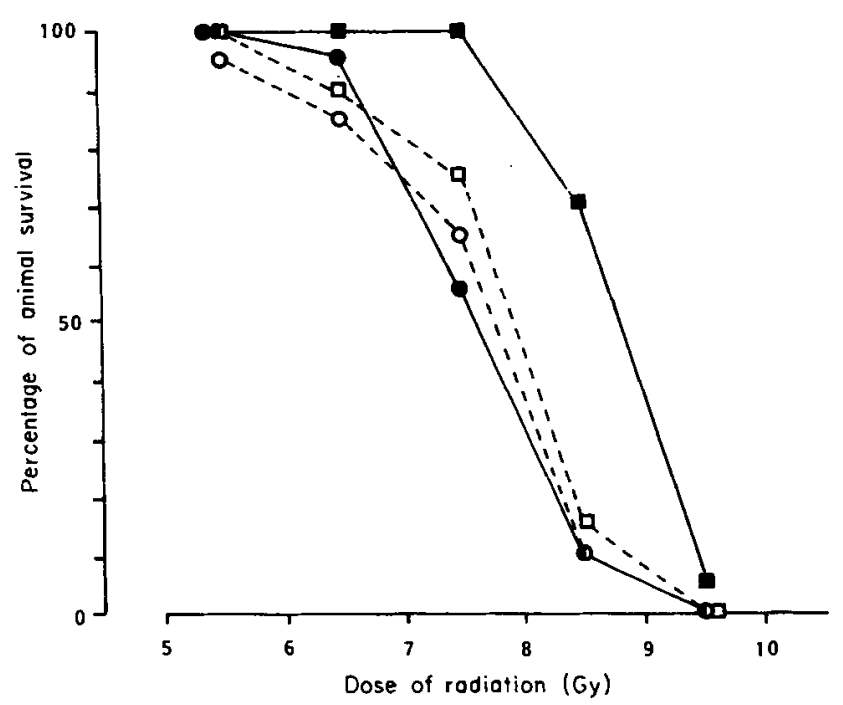

Fig. 2. Protective effect of LPS on the radiation mortality of strain 129 mice following irradiation. $(O, \square), \mathbf{S i} /+$ mice, $(\Theta, \square),+1+$ mice. Circles, irradiation alone; squares, $10 \mu \mathrm{g}$ of LPS $24 \mathrm{hr}$ before irradiation.

Table 1. Radioprotective effects of LPS-W on lifespan and haemopoietic colony-forming units in $\mathrm{S} /+$ and $+/+$ mice

\begin{tabular}{lcc}
\hline & \multicolumn{2}{c}{ Genotype } \\
\cline { 2 - 3 } $\mathrm{DMF}^{*}$ as measured by & $+1+$ & $\mathrm{Sj} /+$ \\
\hline $\begin{array}{l}\text { Endogenous CFU counts } \\
\text { in spleen } \dagger \\
\begin{array}{c}\text { Animal survival } \\
(\mathrm{LD} \mathrm{50/30}) \ddagger\end{array}\end{array}$ & $1.45(P<0.005)$ & $1.76(P<0.05)$ \\
\hline
\end{tabular}

* Dose modification factor calculated from data in Figs 1 and 2 for LPS-treated mice compared with balanced salt solution-injected mice of the same genotype.

† The ratios of radiation doses resulting in 4,10 and 20 spleen colonies (Fig. 1) were calculated and averaged.

$\ddagger$ Radiation dose between 5.5 and 9.5 Gy (see Fig. 2).

$P$ values were calculated relative to the absence of effect $(D M F=1$ ).

\section{CFU-S content and ${ }^{59} \mathrm{Fe}-u p t a k e$ of spleen and bone marrow}

Normal and mutant mice were irradiated with doses that induced a comparable decline in the haemopoietic activity in their spleen and femurs (5.44 and 4.02 Gy, respectively). The previous experiments indicated that LPS-pretreated $+1+$ mice needed a higher dose than BSS-injected animals to obtain a similar CFU-end number, thus the LPS-pretreated mutant and normal mice received an extra $2.07 \mathrm{~Gy}$.

Directly after irradiation and after nine days, spleens and femora were assayed for their CFU-S content. The erythropoietic activity was also determined by measuring the 6 - $\mathrm{hr}{ }^{59} \mathrm{Fe}$ incorporation in the spleen and femurs at Day 2 and 9. Irradiation induced a similar dose-related reduction in CFU-S numbers in the spleens and femurs of both $+/+$ and $\mathrm{Sl} /+$ mice when 
measured $2 \mathrm{hr}$ after irradiation (Table 2). LPS injection led to a threefold increase in both CFUend and CFU-S numbers at Day 9 in the spleen of $\mathrm{Sl} /$ + mice compared to the same animals that received no LPS and that were irradiated with 2 Gy less (Table 2). In $+/+$ mice under these conditions, CFU-end numbers were maintained and spleen CFU-S numbers at Day 9 were halved. The high dose of radiation reduced the total bone marrow content of CFU-S at Day 9 in LPS-injected $\mathrm{Sij} /+$ mice significantly less than in LPS-injected $+1+$ mice, compared to the non-LPS-injected and less heavily irradiated mice of the respective genotypes.

The erythropoietic activity (Table 3 ) in the bone marrow and the spleen of $\mathbf{S j} /+$ and $+1+$ mice was similar under these experimental conditions. Remarkably, a far lower erythropoietic

Table 2. Radioprotective effects of $10 \mu \mathrm{g}$ of LPS-W on post-irradiation recovery in $\mathrm{S} \mathbf{j} /+$ and $+/+$ mice

\begin{tabular}{|c|c|c|c|c|c|c|c|c|c|}
\hline \multirow[b]{3}{*}{ Genotype } & \multirow[b]{3}{*}{ Pretreatment ${ }^{*}$} & \multirow{3}{*}{$\begin{array}{l}\text { Radiation } \\
\text { dose (Gy) }\end{array}$} & \multirow{3}{*}{$\begin{array}{c}\text { Number of } \\
\text { CFU-end } \dagger \\
\text { (day 9) }\end{array}$} & \multicolumn{4}{|c|}{ Number of CFU-S on } & \multirow{2}{*}{\multicolumn{2}{|c|}{$\begin{array}{l}\text { Pre-irradiation } \\
\text { CFU-S number in }\end{array}$}} \\
\hline & & & & \multicolumn{2}{|r|}{ Day 0} & \multicolumn{2}{|c|}{ Day 9} & & \\
\hline & & & & Spleen & Total BM & Spleen & Total BM & Spleen & Total BM \\
\hline$+1+$ & BSS $^{*}$ & $5 \cdot 44$ & $\begin{array}{l}10.8 \\
(1.6)\end{array}$ & $\begin{array}{c}10 \\
(10)\end{array}$ & $\begin{array}{l}170 \\
(50)\end{array}$ & $\begin{array}{l}1164 \\
(249)\end{array}$ & $\begin{array}{c}50,300 \\
(9050)\end{array}$ & $\begin{array}{l}4432 \\
(574)\end{array}$ & $\begin{array}{c}66,600 \\
(7200)\end{array}$ \\
\hline$+1+$ & LPS* & $7.51 \S$ & $\begin{array}{l}10 \cdot 7 \\
(0 \cdot 3)\end{array}$ & $\begin{array}{l}<2 \\
(2)\end{array}$ & $\begin{array}{c}16 \\
(16)\end{array}$ & $\begin{array}{c}556 \\
(177)\end{array}$ & $\begin{array}{c}12,300 \\
(2700)\end{array}$ & 一 & - \\
\hline $\mathrm{Sl} u /+$ & BSS & 4.02 & $\begin{array}{c}6.0 \\
(1.0)\end{array}$ & $\begin{array}{c}17 \\
(12)\end{array}$ & $\begin{array}{c}581 \\
(180)\end{array}$ & $\begin{array}{c}734 \\
(138)\end{array}$ & $\begin{array}{c}71,600 \\
(7880)\end{array}$ & $\begin{array}{l}1701 \\
(328)\end{array}$ & $\begin{array}{c}56,500 \\
(7600)\end{array}$ \\
\hline $\mathbf{S l}^{\mathrm{j} /+}+$ & LPS & $6.09 \S$ & $\begin{array}{l}19.9 \\
(3 \cdot 3)\end{array}$ & $\begin{array}{l}<2 \\
(2)\end{array}$ & $\begin{array}{c}40 \\
(35)\end{array}$ & $\begin{array}{l}2350 \\
(494)\end{array}$ & $\begin{array}{r}37,400 \\
(4860)\end{array}$ & 一 & - \\
\hline
\end{tabular}

Data represent the arithmetic means (1 SE) of three separate experiments. In any one experiment 12 mice per experimental point were used in the CFU-end assay, four as donors for cell suspensions assayed with the CFS-S assay.

* $10 \mu \mathrm{g}$ of LPS in balanced salt solution (BSS) or BSS alone were injected i.v. one day before irradiation. †Endogenous spleen colony formation.

$\ddagger$ Total bone marrow CFU-S number on the assumption that one femur equals $5.9 \%$ of total BM nucleated cells.

$\S$ For both $+/+$ and $\mathrm{Sj} /+$ mice the radiation dose following pretreatment with LPS was increased by $2 \cdot 07 \mathrm{~Gy}$.

Table 3. Erythropoietic activity in bone marrow and spleen of $+1+$ and $\mathrm{Sl}^{\mathrm{j}} /+$ mice

\begin{tabular}{|c|c|c|c|c|c|c|c|c|}
\hline \multirow[b]{3}{*}{ Genotype } & \multirow[b]{3}{*}{ Pretreatment } & \multirow{3}{*}{$\begin{array}{l}\text { Radiation } \\
\text { dose }(G y)\end{array}$} & \multirow{2}{*}{\multicolumn{2}{|c|}{$\begin{array}{c}\text { Cellularity } \times 10^{7} \text { on } \\
\text { day } 9\end{array}$}} & \multicolumn{4}{|c|}{ Percentage ${ }^{59} \mathrm{Fe}$ uptake on } \\
\hline & & & & & \multicolumn{2}{|c|}{ Day 2} & \multicolumn{2}{|c|}{ Day 9} \\
\hline & & & Spleen & Total BM & Spleen & Total BM & Spleen & Total BM \\
\hline$+1+$ & BSS & 5.44 & $\begin{array}{c}4 \cdot 0 \\
(0 \cdot 7)\end{array}$ & $\begin{array}{l}36.0 \\
(1.8)\end{array}$ & $\begin{array}{l}0.36 \\
(0.08)\end{array}$ & $\begin{array}{l}11.7 \\
(1.2)\end{array}$ & $\begin{array}{c}11.4 \\
(3.0)\end{array}$ & $\begin{array}{l}41 \cdot 5 \\
(4 \cdot 5)\end{array}$ \\
\hline$+1+$ & LPS & $7 \cdot 51$ & $\begin{array}{c}2 \cdot 9 \\
(0 \cdot 2)\end{array}$ & $\begin{array}{l}23 \cdot 9 \\
(1 \cdot 1)\end{array}$ & $\begin{array}{c}0.24 \\
(0.04)\end{array}$ & $\begin{array}{l}10 \cdot 6 \\
(2 \cdot 4)\end{array}$ & $\begin{array}{l}10-9 \\
(5-3)\end{array}$ & $\begin{array}{l}19 \cdot 6 \\
(7 \cdot 1)\end{array}$ \\
\hline $\mathbf{S i} /+$ & BSS & $4 \cdot 02$ & $\begin{array}{c}5 \cdot 3 \\
(0.4)\end{array}$ & $\begin{array}{l}31.5 \\
(1.7)\end{array}$ & $\begin{array}{c}0.70 \\
(0.25)\end{array}$ & $\begin{array}{l}14 \cdot 4 \\
(1.6)\end{array}$ & $\begin{array}{c}7.6 \\
(1.9)\end{array}$ & $\begin{array}{l}45 \cdot 5 \\
(5 \cdot 6)\end{array}$ \\
\hline $\mathrm{Sl} /+$ & LPS & $6 \cdot 09$ & $\begin{array}{c}8.2 \\
(0.7)\end{array}$ & $\begin{array}{l}14.0 \\
(1.9)\end{array}$ & $\begin{array}{c}0.22 \\
(0.02)\end{array}$ & $\begin{array}{l}10.0 \\
(1-6)\end{array}$ & $\begin{array}{c}9.6 \\
(1.9)\end{array}$ & $\begin{array}{l}21.8 \\
(5.4)\end{array}$ \\
\hline
\end{tabular}

Data represent the arithmetic mean (1 SE) of three separate experiments. In any one experiment six mice per experimental point were used in the ${ }^{59} \mathrm{Fe}$-incorporation assay.

For further explanation see legend Table 2. 
activity was found in the spleens of LPS-pretreated mutant mice than was suggested from the large radioprotective effect of LPS on the splenic CFU-end and CFU-S survival data (Table 2). The effect of LPS on the cellularity of the spleens of $\mathrm{Sl} /+$ and $+1+$ mice showed the same tendency as was found by an assay of their CFU-S content. Bone marrow cellularity in $\mathrm{Sl} /+$ mice was lower than expected on the basis of their CFU-S content on Day 9.

These data indicate that the parameters used in this study to estimate the radioprotective effect of LPS on haemopoietic activity render information which is incompatible with the data on animal survival. This conclusion applied particularly to the mutant mice that carry a $\mathrm{Sl}^{\mathrm{j}}$ allele.

\section{DISCUSSION}

The aim of the present work was to further investigate the effect of small doses of bacterial lipopolysaccharides upon the apparent enhanced endogenous spleen colony numbers, where animal survival and marrow recovery were less increased or absent (Brecher \& Smith, 1965; Smith et al., 1966a; Mori \& Kitamura, 1976; Fujita et al., 1983). Intensive studies have confirmed the important role of the spleen in the recovery of irradiated haemopoietic stem cells (Playfair \& Cole, 1965; Wolf \& Trentin, 1968; Schofield \& Cole, 1968; Lozzio \& Machado, 1975; Mori \& Kitamura, 1976). The micro-environment of the spleen plays an important role in the short-term response of the haemopoietic system to acute radiation damage, whereas the bone marrow has been suggested to be a requisite for the long-term maintenance or the recovery of fully pluripotent stem cells (Mori \& Kitamura, 1976). The mechanism in the spleen, which is responsible for the radioprotective effects of LPS, is unknown. Various authors proposed that the increased survival can be attributed to a blockade of the mononuclear phagocyte system (MPS) (Smith et al., 1955; Mori \& Nakamura, 1970). However, injection of an appropriate amount of LPS into animals is known to stimulate phagocytic activity, while carbon particles suppress this activity (Nakamura \& Mori, 1974). In fact, the MPS blockade by large doses of colloid appears to be due to depletion of serum opsonins, and not to saturation of the phagocytic cells by the colloid (Jenkin \& Rowley, 1961). The observaton that latex-induced radiation protection of CFU-S was not mediated by serum opsonins or any other serum compound, while no radiation protection was induced in mice by depletion of their complement system (Ploemacher \& van Soest, 1979), make it unlikely that increased survival can be attributed to a blockade of the mononuclear phagocyte system. However, macrophage-mediated induction of haemopoietic regulators in haemopoietic tissues or serum might represent a mechanism involved in the effect of certain radioprotective drugs (Ploemacher et al., 1979; Fujita et al., 1983). In addition, it has been suggested that various other factors may account for this mechanism, e.g. an increased migration of CFU-S to the spleen from other sites and a shortened post-irradiation division delay of CFU-S (Hanks \& Ainsworth, 1967; Millar et al., 1978). Indeed, LPS is known to mobilize bone marrow CFU-S rapidly into the peripheral blood and induce migration of CFU-S to the spleen (Hanks \& Ainsworth, 1967; Vos et al., 1972).

It occurred to us that mutant $\mathrm{Si} /+$ mice and their normal littermates would represent a suitable model to evaluate the role of the spleen and CFU-S migration to the spleen with respect to the radioprotective effect of LPS. Their splenic CFU-S content (Table 2) amounts to only $38 \%$ of that found in the $+/+$ mice, while their femoral CFU-S population size is in the slightly subnormal ranges $(85 \%)$.

Since splenic and femoral CFU-S in normal and mutant ' 129 ' mice have a similar sensitivity to gamma-radiation and stem cell activating factor (SAF) and the level of serum SAF does not differ in these mice following LPS injection (Ploemacher et al., 1984b; Ploemacher \& Brons, 1984), it can be inferred that the endogenous spleen colonies that can be counted nine days after 
irradiation indicate the number of CFU-S that have survived in the spleen and have the capacity to proliferate (Till \& McCulloch, 1963). This assumption is supported by the observation of Smith et al. (1966b) that extrapolation of the survival curve for CFU-end to the $y$-intercept is in close agreement with the estimate of pre-irradiation splenic CFU-S numbers. Moreover, in $\mathrm{S}^{\mathrm{j}} /+$ and $+1+$ mice, CFU-end numbers in non-LPS-injected mice mirrored the pre-irradiation content of splenic CFU-S. If LPS induce CFU-S to migrate from the bone marrow pool, containing approximately $75,000 \mathrm{CFU}-\mathrm{S}$ in mutant mice, to the spleen (containing less than 2000 CFU-S), this could easily lead to significant overestimation of the splenic CFU-S survival rate in situ, even when migration rates were low. Thus, the relative differences in the splenic CFU-end numbers in normal and mutant mice would become smaller, if not undetectable, since the total bone marrow content of CFU-S is similar in these mice. The present data are essentially in line with this concept. It would therefore appear that migration of CFU-S to the spleen in LPS-treated sublethally irradiated mice might have contributed to the large increase in splenic CFU-end numbers. This assumption is supported by the observation (Table 2), that the surviving CFU-S numbers in the spleens of LPS-injected normal and mutant mice reflect the pre-irradiation femoral CFU-S population sizes rather than those measured in the respective unirradiated spleens.

The virtual lack of a radioprotective effect of LPS on the survival of $\mathrm{Sj} /+$ mice is reminiscent of the low degree of protection induced by pre-irradiation bleeding or colloidal carbon injection observed in splenectomized mice (Marsh et al., 1971; Mori \& Kitamura, 1976). If one bears in mind that $\mathrm{Si} /+$ mice are characterized by a deficiency in the haemopoietic stroma, which is most apparent in their spleen (Ploemacher \& Brons, 1984), such a similarity suggests that the stroma of the spleen mediates the radioprotective effect of certain drugs (e.g. LPS, colloidal carbon) on the short-term animal survival. The finding that profound anaemia developed eventually in irradiated splenectomized mice when they were restored with spleen nodule cells (Playfair \& Cole 1965; Schofield \& Cole, 1968) suggests that the spleen may also determine long-term repopulation of irradiated mice.

The present data imply that under certain conditions, none of the four parameters used as correlators and predictors of animal survival (i.e. the CFU-end and CFU-S numbers, ${ }^{59} \mathrm{Fe}-$ uptake and cellularity of haemopoietic organs) are to be relied upon. This may be of importance for the application of these parameters for radioprotective drug screening (Kinnamon et al., 1980).

\section{ACK NOWLEDGMENTS}

We would like to thank Professor Dr O. Vos and Dr K. G. M. Brockbank for critically reviewing this manuscript and Mrs C. J. M. Meijerink-Clerkx for typing the manuscript. This investigation is supported by a program grant of the Netherlands Foundation for Medical Research (FUNGO).

\section{REFERENCES}

BRECHER, G. \& SMITH, W.W. (1965) Dissociation between spleen colony formation and bone marrow recovery in colchicine-treated irradiated mice. Radiat. Res. 25, 176.

BRECHER, G., SMITH, W.W., WILSON, S. \& FRED, S. (1967) Kinetics of colchicine-induced haemopoietic recovery in irradiated mice. Radiat. Res. 30, 600.

Fujita, J., Yoshida, O., Tsurusawa, M., IzUMI, H. \& MORI, K.J. (1983) Effects of reticuloendothelial system blockade on haemopoietic response to irradiation of LPS-non-responsive $\mathrm{C} 3 \mathrm{H} / \mathrm{HeJ}$ mice. Cell Tissue Kinet. 1 , 107. 
HANKs, G.E. \& AINSwORTH, E.J. (1967) Endotoxin protection and colony-forming units. Radiat. Res. $32,367$.

JENKIN, C.R. \& RowLEY, D. (1961) The role of opsonins in the clearance of living and inert particles by cells of the reticuloendothelial system. J. Exp. Med. 114, 363.

Kinnamon, K.E., KetTerling, L.L., Stampfi, H.F. \& Grenan, M.M. (1980) Mouse endogenous spleen counts. A means of screening for anti-radiation drugs. Proc. Soc. Exp. Biol. Med. 164, 370.

LozZio, B.B. \& MACHADO, E.A. (1975) Influence of a neonatal spleen transplant on hematopoiesis of hereditarily asplenic mice. Exp. Haemat. 3, 156.

Marsh, J.C., Boggs, D.R., Chervenck, P.A., Cartwright, G.E. \& Wintrobe, M.M. (1971) Factors influencing hematopoietic spleen colony formation in irradiated mice. IV. The effect of erythropoietic stimuli. J. Cell. Physiol. 71, 65.

MefFerd, R.B., Hendel, D.T. \& LoefFer, J.B. (1953). Effect of Piromen on survival of irradiated mice. Proc. Soc. Exp. Biol. Med. 85, 53.

MILLAR, J.L., BLACKETT, N.M. \& HUYDSPITH, BN. (1978) Enhanced post-irradiation recovery of the haemopoietic system in animals pretreated with a variety of cytotoxic agents. Cell Tissue Kinet. 11, 543.

MORI, K.J. \& KItAMURA, Y. (1976) Role of the spleen in carbon-induced radioprotection. Int. J. Radiat. Biol. 30 , 487.

MORI, K.J., KUMAGI, K. \& ITO, Y. (1978) Difference in the mechanism of radioprotection between carbon particles and bacterial endotoxin. J. Radiat. Res. 19, 283.

MoRi, K.J. \& NakAmURA, S. (1970) Radioprotective effect of RES-blockade in mice. Experientia 26, 1386.

NAKAMURA, S. \& MORI, K.J. (1974) Effect of carbon particles on phagocytic activity of reticuloendothelial system in X-irradiated mice. J. Radiat. Res. 15, 14.

PlayfaIR, J.H.L. \& COLE, L.J. (1965) A fatal anemia in splenectomized irradiated mice protected with isogeneic spleen colony cells. Nature $206,419$.

Ploemacher, R.E. \& VAN SOEST, P.L. (1979) Investigation of opsonin involvement in post irradiation recovery of haemopoietic stem cells (CFU-S). IRCS Med. Sci. Hemat. 7, 271.

PloEmaCHER, R.E., VAN SOEST, P.L., WAGEMAKER, G. \& VAN 'T Hull, E. (1979) Particle-induced erythropoietinindependent effects on erythroid precursor cells in murine bone marrow. Cell Tissue Kinet. 12, 539.

Ploemacher, R.E. \& Brons, N.H.C. (1984) Characteristics of the CFU-S population in mice carrying the SP allele. Cell Tissue Kinet. 17, 1.

Ploemacher, R.E., Brons, N.H.C. \& Nikkels, P.G.J. (1984a) The response of S $j /+$ mice to experimental manipulation of the erythron. Exp. Haemat. 12, 753.

Ploemacher, R.E., Nikkels, P.O.G.J., MolendiJk, W.J., Brons, N.H.C. \& Brockbank, K.G.M. (1984b) Regulation of haemopoietic stem cell proliferation in mice carrying the Sj allele. Cell Tissue Kinet. $17,375$.

SCHOFIELD, R. \& COLE, L.J. (1968) An erythrocyte defect in splenectomized X-irradiated mice restored with spleen colony cells. Br. J. Haematol. 14, 131 .

Smith, F., Smith, W.W., ANDrews, H.L. \& Grenan, M.M. (1955) Effect of parenteral injections of particulate matter on survival of X-irradiated animals. Am. J. Physiol. 182, 396.

SMith, W.W., Alderman, I.M., SCHNEIDER, C.A. \& CORNFIELD, J. (1963) Effect of pretreatment with colchicine or a colchicine derivative on hemopoiesis in irradiated mice. Radiat. Res 19, 621.

SMITH, W.W., BUdD, R.A. \& CoRnFIELD, J. (1966a) Estimation of radiation dose-reduction factor for $\beta$-mercaptoethylamine by endogenous spleen colony counts. Radiat. Res. $27,363$.

SMITH, W.W., BRECHER, G., FRED, S. \& BuDD, R.A. (1966b) Effect of endotoxin on the kinetics of hemopoietic colony-forming cells in irradiated mice. Radiat. Res. 27, 710.

TIL.L. J.E. \& MCCULLOCH, E.A. (1961) A direct measurement of the radiation sensitivity of normal bone marrow cells. Radiat. Res. 14, 213.

TILL, J.E. \& MCCULLOCH, E.A. (1963) Early repair processes in marrow cells irradiated and proliferating in vivo. Radiat. Res. 18, 96.

Vos, O., BuUrman, W.A. \& Plozmacher, R.E. (1972) Mobilization of haemopoietic stem cells (CFU) into the peripheral blood of the mouse; effects of endotoxin and other compounds. Cell Tissue Kinet. 5, 467.

WOLF, N.S. \& TRENTIN, J.J. (1968) Hemopoietic colony studies. V. Effect of hemopoietic organ stroma on differentiation of pluripotent stem cells. J. Exp. Med. 127, 205. 